\title{
Assessing the Ground Water Quality in Sagamu Town, Ogun State, South West Nigeria
}

\author{
${ }^{* 1}$ Mutiu A. Alabi, ${ }^{2}$ Gbolahan Idowu, ${ }^{3}$ Olalekan H. Oyefuga, ${ }^{4}$ Rita M. \\ Sunday, ${ }^{1}$ Temitope Olowokere, ${ }^{1}$ Folake G. Osanaiye and ${ }^{1}$ Stella Odiaka \\ ${ }^{I}$ Molecular Biology/Bioinformatics Unit, Bioresources Development Centre, National Biotechnology \\ Development Agency, Ogbomosho, Nigeria. \\ ${ }^{2}$ Physiology Department, Obafemi Awolowo College of Health Sciences, Faculty of Basic Medical Sciences, \\ Olabisi Onabanjo University, Ago-Iwoye, Nigeria. \\ ${ }^{3}$ Molecular Biology/Bioinformatics Unit, Bioresources Development Centre, National Biotechnology \\ Development Agency, Owode, Nigeria. \\ ${ }^{4}$ Department of Pharmacology, Faculty of Pharmacy, Obafemi Awolowo University, Ile-Ife, Nigeria.
}

\begin{abstract}
An assessment of the groundwater quality of well and bore holes was carried out in Sagamu Town, Ogun State. Sagamu Local Government Area of Ogun State, a semi-urban settlement, southwest Nigeria and falls under the rain forest agro-ecological zone. The study was aimed at examining the various sources of groundwater, the potential pollutants in the groundwater and the quality of the groundwater as it relates to public health. The study identified two sources of groundwater supply namely, boreholes and wells. Groundwater samples (12) were taken from boreholes and wells and subjected to physical, chemical and biological analysis. The results were compared with WHO standards. The results from the laboratory analysis revealed evidences of pollution from both chemical and biological sources. These were evident from high levels of nitrite (4.46 to $7.08 \mathrm{mg} / \mathrm{l})$, lead (0.004 to $0.026 \mathrm{mg} / \mathrm{l})$, copper (0.011 to $0.098 \mathrm{mg} / \mathrm{l})$, nickel (0.009 to 0.042 $\mathrm{mg} / \mathrm{l}$ ) and iron (0.089 to 3.461), and the presence of bacteria, coliforms and fungi. It was further established that the boreholes and wells were more polluted in areas nearer farms and sanitation units than the areas further away from them. Improper sanitation management and improper education for farmers on farming skills could be the major problem for groundwater quality of the study areas. Also, relevant agencies should make continuous effort to control, regulate and educate the people and those using the water on indiscriminate waste disposal from laundry, domestic and agriculture within the study area.
\end{abstract}

Keywords: groundwater, pollutant, bacteria, boreholes, wells.

\section{Introduction}

Nigeria is located in West Africa and has variable terrain. The climate ranges from equatorial in the south to tropical in the centre and arid in the north. Climatic variations influence the vegetations, ranging from mangrove swamps in the south, tropical rainforest in the centre, savannah in the north and sahel savannah in the north - east. The annual rainfall varies from $4000 \mathrm{~mm}$ in the south and $250 \mathrm{~mm}$ in the north with a national average of $1180 \mathrm{~mm}$ [1]. Geological reports gave rock types as Precambrian basement in the southwest, southeast and north-central. The rocks include gneisses, schists, migmatites, pegmatite, charnockitic and quartz-schist $[2,3]$.

Groundwater is an important water resource in both the urban and rural areas of Nigeria but in the cities, pipeborne water is also available. Rural dwellers rely basically on hand-dug wells for potable water supply as the streams usually dry up in dry season. These resources are under threat from pollution either from human life style manifested by the low level of hygiene practiced in the developing nations $[4,5,6]$. Environmental health involves all the factors, circumstances and conditions in the environment or surroundings of humans that can influence health and well being. The neglect of rural areas in most developing countries in terms of basic infrastructures such as pipe-borne water and sanitation facilities, expose the villagers to a variety of health related problems such as water - borne diseases [7].

Water is important to life, without it life cannot go on. Domenico [8] said it all when he stated that human life as with animals and plant life on the planet is dependent on water. Because of the intimate relationship between water and life, water can be said to be woven into fabric of all cultures, religious societies in myriad ways. Water on the earth can be said to be enormous in quantity when it is considered that more than two-thirds of the earth surface is covered by water [9]. But UNEP and WHO [10] argued that it is not sufficient merely to have access to water in adequate quantities, the water also needs o be of adequate quality to maintain health and it must be free from harmful biological and chemical contamination.

Dauda [11] observed that as surface water becomes increasingly polluted, people turn to groundwater for alternative supplies. Therefore the development and efficient management of groundwater resources is of 
particular concern in the Middle East, Africa and Latin America, particularly the Sudano-Sahelian belt [12]. In these areas not only is there relative scarcity of water resources and quality degradation but also they face high evaporation rates and high levels of anticipated future demands [13].

Marte [14] stated that groundwater accounts for over $80 \%$ of the domestic water supply in the Sahelian region of Nigeria. Bama town, which is in the Sahelian region of Nigeria, also faces relative scarcity of water and quality degradation. The goal of all countries is to increase economic production as it is generally thought that this will result in a better life for the citizens. In as much as the population of the country is growing, it is likely that the total use of water will increase [15]. Babaji and Ndubusi [16] said that runoffs from the scarce rainfall of the region are being charged with ever increasing loads of organic and mineral impurities that naturally recharge the aquifers.

The most common source of groundwater pollution is from substances used in forestry, waste and agriculture such as insecticide, herbicide and fungicide. The constituents of many of the pesticides are highly toxic, even in minute amounts [17]. Nitrogen-based fertilizers are the most commonly identifiable pollutant in groundwater in rural areas [14]. Nitrogen in the form of dissolved nitrate is the major nutrient for vegetation, when applied some nitrate is retained by plants and soil particles. However, if applied in excessive amounts, the excess nitrate not consumed by plants can be flushed down to groundwater. Although nitrate is relatively nontoxic it can cause certain conditions, a serious blood disorder in infants [13].

The greatest danger associated with drinking water is that, it may be polluted by human or animal waste and leads to ingestion of dangerous pathogens. The organisms most commonly used as indicators of pollution are colliform bacteria [18]. Sanitation units, such as septic system and latrines are designed to discharge domestic waste water into the sub-surface. The increase in human activities has produce quantities of waste greater than the environment can absorb. Large volumes of domestic, commercial and industrial waste keep on accumulating in and around the cities and villages [13].

Urbanisation and the unregulated growth of the parameters population have altered the surface and subsurface terrains of the many areas. Changes in local topography and drainage system directly affect both quality and quantity of the ground water $[19,20]$. Inadequate environmental protection measures in the coal mining base are and related industries as well as the presence of active and abandoned coal mines, waste dumps, coal washeries, coking coal plants, thermal power plants, steel, fertilizer and cement plants have resulted in significant water tool pollution [21].

Groundwater quality depends on the quality of recharged water, atmospheric precipitation, inland surface water and sub-surface geochemical processes. Temporal changes in the origin and constitution of the recharged water, hydrologic and human factors may cause periodic changes in groundwater quality. Water pollution not only affects water quality but also threats human health, economic development and social prosperity [22,23]. River basins are highly vulnerable to pollution due to absorption and transportation of domestic, industrial and agricultural waste water; therefore, it is significant to control water pollution and importance in the overall quality of water for drinking monitor water quality [24,25].

Various geo-statistical concepts are used for the interpretation of complex data sets which allows a better understanding of the water quality parameters $[26,27,28]$. Risk assessment involves identifying the hazard associated with a particular occurrence, action, or circumstance and determination the probability for the occurrence of such hazards [29]. Hence, evaluation of groundwater quantity and quality and establishing data base are important for the development of further civilization and for future water resources development strategies.

Therefore groundwater resource assessment becomes an important issue to consider, as it would be of great importance to individuals, especially the inhabitants of the area, who would know the effect of their activities on the quality of groundwater, environment and health.

The objectives of this study were to assess the quality of ground water from wells and boreholes in Sagamu town, Sagamu Local Government Area of Ogun State to determine the factors affecting the quality of the ground water and to make policy statements to government of maintenance of quality ground water.

The outcome of this research could be beneficial Local, State, and Federal Governments as it will be useful in policy formulation, implementation, monitoring and evaluation, especially on issues relating to water and sanitation management.

\section{Study Area}

\section{Materials And Methods}

The study area, Sagamu town, Ogun State, southwest Nigeria, situated on longitude $7.5^{\circ} \mathrm{N}$ and latitude $3.25^{\circ} \mathrm{N}$ and has derived savanna vegetation, described with Precambrian crystalline basement complex rocks. The dominant rocks constitute suites of gneisses and quartzite [1]. The major climatic seasons are wet or rainy season, which begins in March or April, and ends in October and the dry season, which begins in November and ends in March or April. 


\section{Sample Collection}

Water samples were procured from twelve hand-dug wells, whose depths varied from 4 to $12 \mathrm{~m}$, located in the vicinities of municipal solid-waste dumpsites open - air defecation sites, twice a month for period of three months in the dry season and another period of three months in the wet season.

\section{Analytical Methods}

Water physicochemical and bacteriological parameters analyzed in accordance to standard methods of APHA [30] were $\mathrm{pH}$, temperature, electrical conductivity (EC), hardness, total dissolved solids (TDS), turbidity, nitrate $\left(\mathrm{NO}_{3}{ }^{-}\right)$, sulphate $\left(\mathrm{SO}_{4}{ }^{2-}\right)$, chloride $\left(\mathrm{Cl}^{-}\right)$, dissolved oxygen (DO), chemical oxygen demand (COD), biochemical oxygen demand (BOD), fecal coliform (FC) and total coliform (TC) counts.

Trace elements namely iron $(\mathrm{Fe})$, copper $(\mathrm{Cu})$, lead $(\mathrm{Pb})$, nickel $(\mathrm{Ni})$, zinc $(\mathrm{Zn})$ chromium $(\mathrm{Cr})$ and cadmium $(\mathrm{Cd})$ were analyzed using atomic absorption spectrophotometer (AAS). Analyses were carried out as per standard methods of APHA [30].

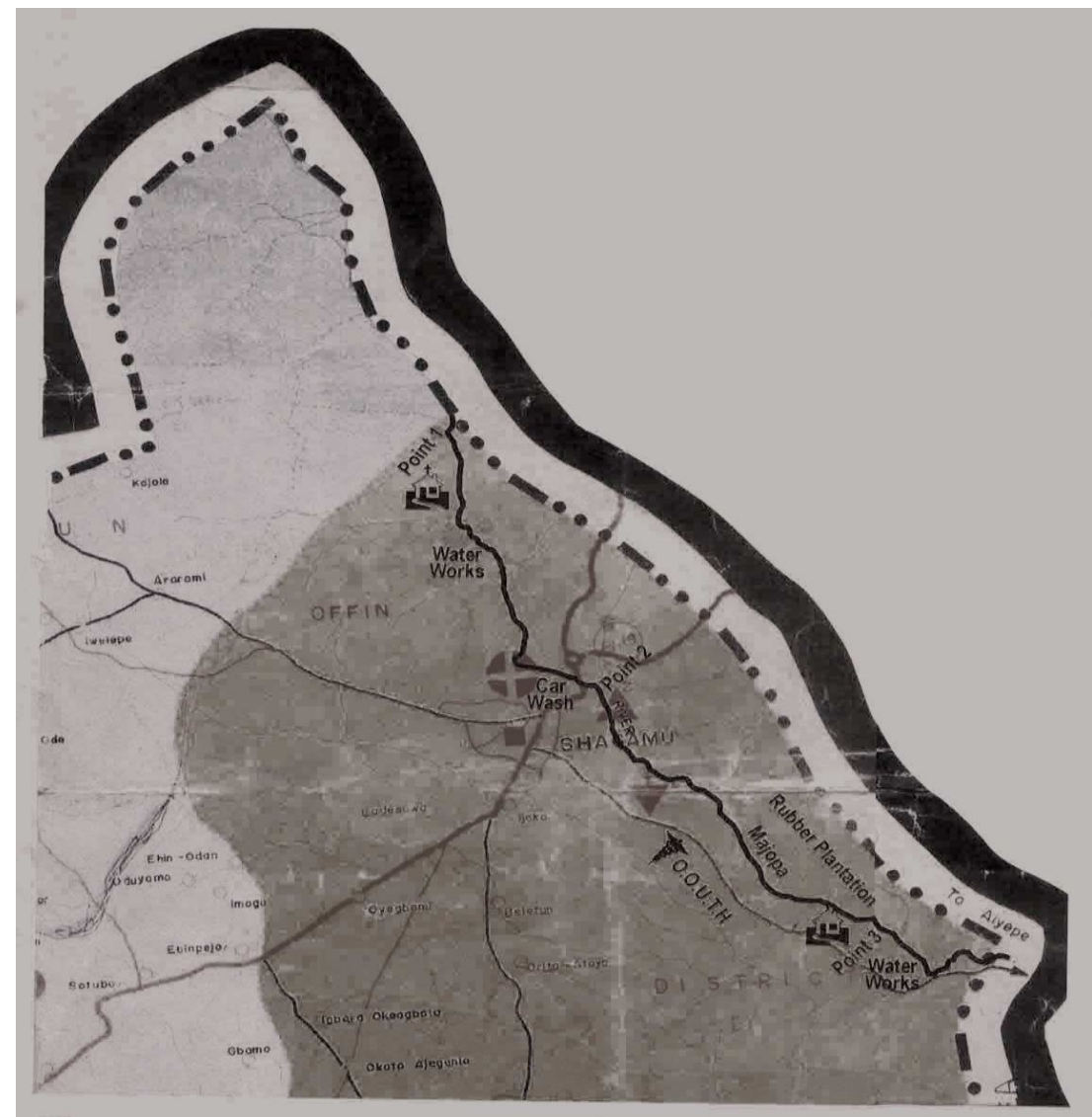

Figure 1: Map of Sagamu Local Government showing River Majopa

\section{Quality Assurance Procedures}

Special precautions taken for quality assurance were as follows; all reagents were of analytical grade, purchased from Aldrich Chemical Company, England and samples for metal analysis were preserved with $3 \mathrm{ml}$ concentrated $\mathrm{HNO}_{3}$ per liter in the field. Samples used for determination of metals, physical properties, $\mathrm{SO}_{4}{ }^{2-}$ and $\mathrm{NO}_{3}{ }^{-}$were collected in plastic bottles and those for the determination of DO, COD, and BOD were collected in specialized glass wares. Samples for DO were treated at the site with $2 \mathrm{ml}$ of manganous sulphate and $2 \mathrm{ml}$ alkaline-iodide-azide solution. Precautions were taken to avoid the trapping of atmospheric oxygen. Quality control measures for pollutants, especially toxic metals include reagent and blank analyses, spiked sample recovery determinations and multiplicity of samples (increased sample population size, $\mathrm{n}=12$ for each determination).

Samples for $\mathrm{COD}, \mathrm{NO}_{3}{ }^{-}$and $\mathrm{SO}_{4}{ }^{2-}$ were refrigerated and analyzed within 24 hours. All plastics and glass wares utilized were pre-washed with detergent water solution, rinsed with tap water and soaked for $48 \mathrm{~h}$ in $50 \% \mathrm{HNO}_{3}$, then rinsed thoroughly with distilled deionized water. They were then air-dried in a dust free 
environment. All containers for bacteriological analysis, in addition to the previous treatments, were sterilized in an autoclave at $121^{\circ} \mathrm{C}$ for 15 minutes. The plastic bottles were not capped to avoid distortion.

\section{Data Analysis}

The results of the assessment of the groundwater were analyzed using descriptive statistics (simple frequency counts percentage) and data collected are presented in tabular form for clarity.

\section{Results}

Table 1: Physicochemical Properties of the Ground Water

\begin{tabular}{|c|c|c|c|c|c|c|c|c|c|c|c|c|c|c|}
\hline & $\mathbf{A}$ & $\mathbf{B}$ & $\mathbf{C}$ & $\mathbf{D}$ & $\mathbf{E}$ & $\mathbf{F}$ & $\mathbf{G}$ & $\mathbf{H}$ & $\mathbf{I}$ & $\mathbf{J}$ & $\mathbf{K}$ & $\mathbf{L}$ & \multicolumn{2}{|c|}{ WHO } \\
\hline $\mathbf{p H}$ & 6.90 & 6.33 & 5.39 & 6.60 & 4.56 & 5.21 & 6.14 & 6.14 & 5.49 & 7.76 & 7.02 & 6.98 & $7.0-$ & $\begin{array}{c}\text { HPL } \\
0 \mathbf{5}\end{array}$ \\
\hline Acidity & 400 & 903 & 3800 & 1890 & 300 & 1300 & 800 & 200 & 300 & 300 & 700 & 1400 & - & - \\
\hline Alkalinity & 164 & 450 & 150 & 204 & 250 & 100 & 96 & 300 & 100 & 50 & 99 & 104 & $80-$ & - \\
\hline Turbidity & 1.50 & 74.0 & 0.40 & 4.67 & 0.43 & 1.42 & 1.34 & 4.76 & 0.43 & 0.98 & 22.8 & 0.95 & - & - \\
\hline $\mathbf{E C}$ & 179 & 183.3 & 26 & 120.1 & 55.7 & 93.7 & 40.2 & 24.9 & 104.9 & 93.2 & 144.1 & 121.2 & $<1000$ & 1000 \\
\hline TDS & 96 & 161 & 224 & 41 & 43 & 69 & 66 & 19 & 91 & 82 & 46 & 24 & 300 & 1000 \\
\hline Hardness & 29 & 215 & 45 & 50 & 50 & 80 & 46 & 20 & 55 & 60 & 59 & 29 & 100 & 500 \\
\hline $\mathbf{S O}_{\mathbf{4}}{ }^{2-}$ & 26.7 & 23.4 & 28.8 & 24.1 & 30.6 & 25.8 & 69.0 & 44.8 & 22.8 & 74.9 & 56.0 & 33.8 & 200 & 500 \\
\hline $\mathbf{N O}_{3}{ }^{-}$ & 6.01 & 6.02 & 5.48 & 4.46 & 8.02 & 4.78 & 5.00 & 5.58 & 6.82 & 7.08 & 5.28 & 4.49 & $<3.0$ & 3.0 \\
\hline $\mathbf{C I}^{-}$ & 28.86 & 14.18 & 14.18 & 28.36 & 42.54 & 28.36 & 99.26 & 56.72 & 85.08 & 354.5 & 28.36 & 42.54 & $<100$ & 600 \\
\hline
\end{tabular}

Note: All values are expressed in $\mathrm{mg} / \mathrm{l}$ except for Turbidity, $\mathrm{pH}$ and Conductivity. Conductivity is expressed in $\mu \mathrm{S} / \mathrm{cm}$. HDL- Highest Desirable Level and MPL-Maximum Permissible Level

Table 2: Trace Metal Quantity of the Ground Water

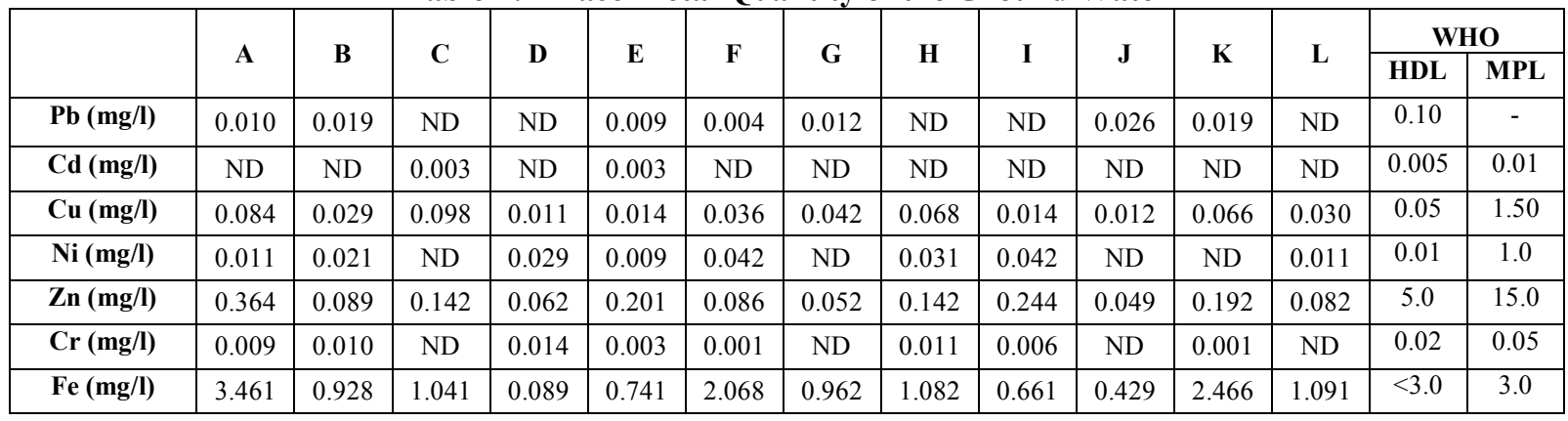

Note: HDL- Highest Desirable Level and MPL-Maximum Permissible Level

Table 3: Bacteriological Properties of the Ground Water

\begin{tabular}{|c|c|c|c|c|c|c|c|c|c|c|c|c|c|}
\hline & $\mathbf{A}$ & B & $\mathrm{C}$ & D & $\mathbf{E}$ & $\mathbf{F}$ & G & $\mathbf{H}$ & I & $\mathbf{J}$ & $\mathbf{K}$ & $\mathbf{L}$ & WH \\
\hline DO & 13.7 & 1.0 & 15.3 & 10.5 & 11.9 & 5.3 & 14.3 & 4.9 & 8.3 & 8.2 & 2.7 & 8.4 & $5-8$ \\
\hline $\begin{array}{c}\text { BO } \\
\text { D }\end{array}$ & 3.1 & 0.1 & 0.1 & 1.7 & 0.7 & 0.9 & 1.1 & 0.8 & 1.1 & 1.0 & 1.7 & 0.6 & 20 \\
\hline $\begin{array}{c}\text { CO } \\
\text { D }\end{array}$ & 16.0 & 8.0 & 8.0 & 8.0 & 7.0 & 8.0 & 12.0 & 8.0 & 4.0 & 4.0 & 4.0 & 12.0 & 100 \\
\hline TB & $\begin{array}{c}1.41 \times 1 \\
0^{6}\end{array}$ & $\begin{array}{c}1.21 \times 1 \\
0^{3}\end{array}$ & $\begin{array}{c}1.27 \times 1 \\
0^{6}\end{array}$ & $\begin{array}{c}1.50 \times 1 \\
0^{2}\end{array}$ & $\begin{array}{c}1.40 \times 1 \\
0^{4}\end{array}$ & $\begin{array}{c}1.32 \times 1 \\
0^{3}\end{array}$ & $\begin{array}{c}1.42 \times 1 \\
0^{6}\end{array}$ & $\begin{array}{c}1.28 \times 1 \\
0^{5}\end{array}$ & $\begin{array}{c}1.10 \mathrm{x} 1 \\
0^{4}\end{array}$ & $\begin{array}{c}1.61 \times 1 \\
0^{3}\end{array}$ & $\begin{array}{c}1.48 \times 1 \\
0^{6}\end{array}$ & $\begin{array}{c}1.33 \times 1 \\
0^{6}\end{array}$ & \\
\hline TC & $\begin{array}{c}1.10 \times 1 \\
0^{2}\end{array}$ & $\begin{array}{c}1.11 \mathrm{x} 1 \\
0^{2}\end{array}$ & $\begin{array}{c}1.20 \mathrm{x} 1 \\
0^{1}\end{array}$ & $\begin{array}{c}1.00 \times 1 \\
0^{4}\end{array}$ & $\begin{array}{c}1.12 \times 1 \\
0^{2}\end{array}$ & $\begin{array}{c}1.18 \times 1 \\
0^{3}\end{array}$ & $\begin{array}{c}1.00 \times 1 \\
0^{3}\end{array}$ & $\begin{array}{c}1.00 \times 1 \\
0^{2}\end{array}$ & $\begin{array}{c}1.10 \mathrm{x} 1 \\
0^{2}\end{array}$ & $\begin{array}{c}1.12 \times 1 \\
0^{2}\end{array}$ & $\begin{array}{c}1.11 \times 1 \\
0^{3}\end{array}$ & $\begin{array}{c}1.14 \times 1 \\
0^{2}\end{array}$ & \\
\hline $\mathbf{T F}$ & $1.2 \times 510$ & $3.1 \times 10$ & $\underset{3}{4.0 \times 10}$ & $2.0 \times 10$ & $\underset{2}{1.0 \times 10}$ & $\underset{1}{4.0 \times 10}$ & $3.0 \times 10$ & $4.0 \times 10$ & $\underset{2}{3.0 \times 10}$ & $\underset{2}{2.0 \times 10}$ & $\underset{2}{5.0 \times 10}$ & $3.1 \times 10$ & \\
\hline
\end{tabular}

Note: All values are expressed in mg/l except for total bacteria (TB) expressed in CFU/10ml, total coliforms (TB) expressed in CFU/1000ml and total fungi (TF) expressed in teat count. 


\section{Discussion}

Table 1 shows the physicochemical properties of the ground water in comparison with WHO standards. The results of the analysis indicate that the $\mathrm{pH}$ values range between 4.56 and 7.76. This shows that the values are below the Highest Desirable Limits and Maximum Permissible Level by WHO standards. This makes the midpoint to be acidic.

The alkalinity values obtained is within range of values between 50 and $450 \mathrm{mg} / \mathrm{l}$ and does not fall within the WHO standard [31] of 80-120 mg/l considered optimum for alkalinity of the water. Therefore, it was found that the amount of total alkalinity (Table 1) was running below the lower limit and above upper limit of optimum range. That might allow for rapid $\mathrm{pH}$ fluctuations, makes $\mathrm{pH}$ control more difficult and might contribute to corrosion $[20,32,33]$. Total acidity results obtained in the analysis is within range of values between 200 and $3800 \mathrm{mg} / 1$.

Turbidity results obtained in the analysis is within range of values between 0.40 and $22.8 \mathrm{mg} / \mathrm{l}$. The results of the analysis indicated that the electrical conductivity values obtained during the study ranged between 24.9 and $183.3 \mu \mathrm{S} / \mathrm{cm}$. This shows that the values are less the desirable limits set by WHO standards [31,34].

The results obtained in the analysis indicate that total dissolved solid (TDS) is between 19 and 224 $\mathrm{mg} / \mathrm{l}$ and above the desirable limits set by FEPA standards $(300 \mathrm{mg} / \mathrm{l})$ with range of values. Also, the hardness values obtained during the study ranged between 20 and $215 \mathrm{mg} / \mathrm{l}$. This shows that the values are within the desirable limits set by WHO standards except for that of Point B that is higher than the WHO standard [31].

The concentrations of sulphate, nitrate and chloride in all the sampling points varied between 22.8 to $74.9 \mathrm{mg} / \mathrm{l}$ for sulphate; 4.46 to $7.08 \mathrm{mg} / \mathrm{l}$ for nitrate and 14.18 to $99.26 \mathrm{mg} / \mathrm{l}$ for chloride respectively (Table 2). Sulphate and chloride concentrations observed were below WHO standard [31] but the levels of nitrate determined are above WHO standard. The levels of nitrate may give rise to methaemoglobinemia $[33,35]$. Also the levels of nitrate reported in this study can cause eutrophication [36] and may pose a problem for other uses.

The concentrations of trace metals in all the sampling points varied between 0.004 to $0.026 \mathrm{mg} / \mathrm{l}$ for lead, $0.003 \mathrm{mg} / \mathrm{l}$ for cadmium, 0.011 to $0.098 \mathrm{mg} / \mathrm{l}$ for copper, 0.009 to $0.042 \mathrm{mg} / 1$ for nickel, 0.049 to 0.364 $\mathrm{mg} / \mathrm{l}$ for zinc, 0.009 to $0.042 \mathrm{mg} / \mathrm{l}$ for chromium and 0.089 to $3.461 \mathrm{mg} / \mathrm{l}$ for iron (Table 4.37). The level of cadmium, zinc and chromium are below WHO standard whereas those of lead, copper, nickel and iron are above the WHO standard [31].

Dissolved oxygen (DO) values obtained for points varied between 1.0 to $15.3 \mathrm{mg} / \mathrm{l}$ as shown in Table 4.38. The WHO standard [31] for sustaining aquatic life is stipulated at $5 \mathrm{mg} / \mathrm{l}$. A concentration below this value adversely affects aquatic biological life [33,37], while concentration below $2 \mathrm{mg} / \mathrm{l}$ may lead to death for most fishes $[38,39]$ and anaerobic conditions that cause bad odours [36,39]. The DO levels at many points are above this level.

An indication of organic oxygen demand content of river water can be obtained by measuring the amount of oxygen required for its stabilization either as BOD and COD [20,35]. BOD and COD concentrations of the river water were measured, as the two were important in unit process design.

BOD concentration of the river water obtained for the points ranged between 0.1 to $3.1 \mathrm{mg} / \mathrm{l}$ (Table 3 ). The concentrations of BOD at the sample point 2 are lower than the WHO standards [31] of $20 \mathrm{mg} / \mathrm{l}$ for river water. BOD indicates the presence of microbial activities and dead organic matter on which microbes can feed. BOD is directly linked with decomposition of dead organic matter present in the wastewater and hence the higher values of BOD can be directly related with pollution status of the wastewater $[33,40]$. The higher value of BOD means present of more biodegradable organic material [41].

The river water has an average COD concentration of 4.0 to $16.0 \mathrm{mg} / \mathrm{l}$ for the points (Table 3) which are lower than the WHO standards [31] of $100 \mathrm{mg} / 1$ for river water. Chemical oxygen demand is defined as the amount of a specified oxidant that reacts with the samples under controlled conditions [30] and is often used as a measurement of pollutants in wastewater and natural water.

High COD and BOD concentration observed in the river water might be due to the use of chemicals, which are organic or inorganic that are oxygen demand in nature.

Total bacteria, total coliforms and total fungi in the present investigation exhibits more counts as shown in Table 3. The concentrations of total balthal, total coliforms and total fungi were in the range of $1.50 \times 10^{2}$ to $1.48 \times 10^{6}, 1.20 \times 10^{1}$ to $1.00 \times 10^{4}$ and $4.0 \times 10^{1}$ to $1.25 \times 10^{5}$ respectively. Increase in total bacteria, total coliforms and total fungi might be due to discharging of domestic wastes containing faecal matters to the river body and open defecation along the sides of river bank [20]. So in all the points, the levels of total bacteria, total coliforms and total fungi of counts of the river water are beyond the permissible limit and were not suitable for drinking purpose without pretreatment.

\section{Conclusion}

Thus the present study was concluded that river water of the study area was not polluted in respect to physico-chemical assessment. But bacteriological studies attributed river water was not fit for drinking purposes 
due to higher coliforms counts, which require continuous monitoring and treatment process if the water is to be used for drinking purposes. Some steps and awareness programs must need to educate local villagers to safeguard the precious river and its surrounding.

Based on the findings of the study, it could be ascertained that the is evidence of both chemical and biological pollution, because of the importance of groundwater as a source of drinking water to so many communities and individuals, the best way to guarantee continued supplies of clean groundwater is to reduce pollution. Government should inform and educate the farmers about voluntary actions through which the farmers can better manage animal waste, apply fertilizers and pesticides according to plant needs and properly schedule irrigation.

Individuals can help by improving their house keeping practices, by learning how to properly dispose of household products containing hazardous substances. Proper safety measures should be taken by individuals by not situating their wells along the flow path of potential pollution sources such as septic tanks, latrines and waste disposal sites and by providing covers for wells and not allowing stagnant water to pond close to the top of the wells.

\section{References}

[1]. Abdulaziz, M. (2003): Spatial variation in water quality in Nguru Urban. Unpublished MSc Project. University of Maiduguri, Nigeria.

[2]. Adediji, A. and Ajibade L. T. (2005): Quality of well water in Ede area, southwest Nigeria. J. Hum. Ecology, $17(3), 223$-228.

[3]. Adekunle, I. M., Arowolo, T. A., Ndahi, N. P., Bello, B. and Owolabi, D. A. (2007): Chemical characteristics of humic acids in relation to lead, copper and cadmium levels in contaminated soils of southwest Nigeria, Annals of Environmental Science, North Eastern University, Boston, Massachusetts USA, 1, 23-34.

[4]. Adeniji, F. A. and John, V. L. (1989): Sources, Availability and Safety of water. Proceedings of International Seminar of Water Resources in the Lake Chad Basin. University of Maiduguri, Nigeria.

[5]. Akan, J.C. Abdulrahman, F.I. Dimari G.A. and Ogugbuaja, V.O. (2008). Physicochemical Determination of Pollutants in Wastewater and Vegetable Samples along the Jakara Wastewater Channelin Kano Metropolis, Kano State, Nigeria. European Journal of Scientific Research. 23 (1); 122-133.

[6]. Akujieze C. N., Coker, S. J. and Oteze, G. E. (2003): Groundwater in Nigeria - a millennium experience - distribution, practice, problems and solutions. Hydrogeology Journal, 1, $259-274$.

[7]. Alagbe, S. A. (2002): Groundwater resources of river Kan Gimi Baisn, north-central, Nigeria. Environmental Geology, 42 , 404 413.

[8]. APHA. (2005). Standard methods for the Examination of Water and Wastewater. 21 st Edition. American Public Health Association, Washington, D.C.

[9]. Aremu, D. A., Olawuyi, J. F., Meshitsuka, S., Sridhar, M. K. and Oluwande, P. A. (2002): Heavy metal analysis of groundwater from Warri, Nigeria. International Journal of Environmental Health Research, 12, 261-267.

[10]. Babaji, I. and Ndubusi, O.L. (1988): Self reliance in community water supply. Proceedings of Seminar on Engineering for community Development, Nigerian Society for Engineers. Maiduguri.

[11]. Chapman, D. (1997). Water Quality Assessment. A Guide to the use of Biota, Sediments and water in Environmental Monitoring. Second Edition. E\& FN Spon, London.

[12]. Chatterjee, R., T. Gourab and S. Paul, (2010). Groundwater quality assessment of Dhanbad district, Jharkhand, India, Bull Eng Geol Environ., 69: 137-141.

[13]. Dauda, A.M. (1993): A Comprehensive approach in water resources management for the 21st century, Environmental Bullets vol.12. Nigeria.

[14]. De A.K. (2002). Environmental Chemistry 4th Edition, New Age International Publishers, New Delhi, $245-252$.

[15]. Domenico, P.A. (1972): Concept and models in groundwater hydrology. New York. McGraw hill.

[16]. Longe, E.O. and Balogun, M.R. (2010). Groundwater Quality Assessment near a Municipal Landfill, Lagos, Nigeria. Research Journal of Applied Sciences, Engineering and Technology 2(1): 39-44.

[17]. Fetter, C.W. (1994): Applied hydrology. University of Wisconsin, USA

[18]. Ikem, A.; Osibanjo, O.; Sridhar, M. K. C.; Sobande, A.: Evaluation of groundwater quality characteristics near two waste sites in Ibadan and Lagos, Nigeria. Water, Air and Soil Pollution, 2002, 140 (1-4), 307-333.

[19]. Isaaks, E.H. and R.M. Srivastava, 1989. An introduction to applied geostatistics. New York: Oxford University.

[20]. Kumar, D. and S. Ahmed, (2003). Seasonal behavior of spatial variability of groundwater level in a granitic aquifer in monsoon climate. Current Sci., 84(2): 188-196.

[21]. Marte, A.M. (1983): The groundwater resources and exploitation in the Chad formation. Unpublished M.Sc. Project, Loughbough University of Technology.

[22]. Milovanovic, M., 2007. Water quality assessment and determination of pollution sources along the Axios/ Vardar River, Southeastern Europe. Desalination, 213: 159-173.

[23]. Molden, D. (Ed). (2007). Water for food, Water for life: A Comprehensive Assessment of Water Management in Agriculture. Earthscan/IWMI,.

[24]. Offodile, M.E. (2002): Groundwater study and development in Nigeria. University of Ibadan Press. Nigeria.

[25]. Punmia B. C.; Jain A. K.: Wastewater Engineering. Laxmi Publications (P) Ltd, New Delhi, 1998.

[26]. Rao, S.N., 2006. Seasonal variation of groundwater quality in a part of Guntur District andhra Pradesh, India. Environmental Geol., 49: 413-429.

[27]. Reza R and Singh G (2010). Assessment of Ground Water Quality Status by Using Water Quality Index Method in Orissa, India.World Applied Sciences Journal 9 (12): 1392-1397.

[28]. Simeonov, V., J.A. Stratis, C. Samara, G. Zachariadis, D. Voutsa and A. Anthemidis, 2003. Assessment of the surface water quality in Northern Greece. Water Res., 37: 4119-4124.

[29]. Smith, K. (2001). Environment hazards: Assessing risk and reducing disaster (3 ed., pp: 324). London: Routlege.

[30]. Sophocleous, M. (2002). "Interactions between groundwater and surface water: the state of the science". Hydrogeology Journal 10: 52-67. 
[31]. SridhaR, M. K. C.: Ground water in Nigerian urban centers: problems and options. Schriftenr Ver Wasser Boden Luftyg., 2000, 105, 393-397.

[32]. Suk, H. and K. Lee, 1999. Characterization of a ground water hydrochemical system through multivariate analysis: Clustering into ground water zones. Ground Water, 37: 358-366.

[33]. Todd, D.K. (1959): Groundwater hydrology. Wiley International Edition.

[34]. UNEP and WHO (1996): Water quality Monitoring. An imprint of Chapman and Hall, London.

[35]. Vasanthavigar, M., K. Srinivasamoorthy, K. Vijayaragavan, R. Ganthi, S. Chidambaram, P. Anandhan, R. Manivannan and S. Vasudevan, 2010. Application of water quality index for groundwater quality assessment: Thirumanimuttar sub-basin, Tamilnadu, India. Environ Monitoring Assess. DOI 10.1007/s10661-009-1302-1.

[36]. Venkatesharaju K., Ravikumar. P., Somashekar. R. K., Prakash. K. L. (2010). Physico-Chemical and Bacteriological Investigation on the River Cauvery Of Kollegal Stretch In Karnataka Kathmandu University Journal Of Science, Engineering And Technology. 6 (1), 50-59.

[37]. Waziri. M. and Ogugbuaja V.O. (2010). Interrelationships between physicochemical water pollution indicators: A case study of River Yobe-Nigeria. Am. J. Sci. Ind. Res., 2010, 1(1): 76-80.

[38]. WHO (2000): Water for Health. World Water Day 2000, Washington.

[39]. WHO (2004). Rolling revision of the WHO guidelines for drinking water quality, Draft for review and comments. World Health Organization, (WHO/SDE/WSH/04.08/56).

[40]. Wright, J. B. (1985). Geology and Mineral Resources of West Africa. Allen \& Unwin, London.

[41]. Yerima, F. A. K. Daura, M. M., and Gambo, B. A. (2008). Assessment of Groundwater Quality of Bama Town, Nigeria. J. of Sustainable Development in Agriculture \& Environment Vol. 3(2):128-137.

[42]. WQM Report. (1999). Annual report on water quality monitoring of upper and lower lakes Bhopal, Volumes I and II

[43]. ICMR (1975). Manual of standard of quality for drinking water supplies Special report series No.44, 2nd edition. 